Supporting information for:

\title{
Identification and Quantification of Technetium Species in Hanford Waste Tank AN-102
}

Sayandev Chatterjee, ${ }^{\dagger}, \epsilon *$ Vanessa E Holfeltz, ${ }^{\dagger, £}$ Gabriel B Hall, ${ }^{\dagger}$ Isaac E Johnson, ${ }^{\dagger}$ Eric D Walter, ${ }^{\dagger}$ Sungsik Lee, ${ }^{\mathrm{F}}$ Benjamin Reinhart, ${ }^{\mathrm{T}}$ Wayne W Lukens, ${ }^{\&}$ Nicholas P Machara ${ }^{\ddagger}$ and Tatiana G Levitskaia ${ }^{\dagger *}$

${ }^{\dagger}$ Energy and Environment Directorate, Pacific Northwest National Laboratory, Richland, Washington 99354, United States

${ }^{\epsilon}$ Present address: ESSENCE Diagnostics LLC, Livingston New Jersey 07039, United States

${ }^{\mathrm{f}}$ Present address: CEA, DEN, DMRC, Univ Montpellier, Marcoule, France

†Environmental Molecular Sciences Laboratory, Pacific Northwest National Laboratory, Richland, Washington 99354, United States

${ }^{\mathrm{F}}$ X-ray Science Division, Argonne National Laboratory, Argonne, Illinois 60439, United States

${ }^{\&}$ Lawrence Berkeley National Laboratory, Berkeley, California 94720, United States

${ }^{\sharp}$ United States Department of Energy, Germantown, Maryland, United States

email: Tatiana.Levitskaia@pnnl.gov ; sayandev@essencediagnostics.com

\section{Table of Contents}

\begin{tabular}{|c|c|c|}
\hline Section S1 & Detailed Experimental Section & S2-S9 \\
\hline & Instruments and procedures & S2-S6 \\
\hline Figure S1 & NMR solution samples placed in PTFE/FEP sleeves inserted into glass tubes & $\mathrm{S} 3$ \\
\hline Figure S2 & Design of the triple containment XAS cell for Tc liquid samples & S4 \\
\hline Figure S3 & Design of the triple containment XAS cell for Tc solid samples & $\mathrm{S} 5$ \\
\hline \multirow[t]{2}{*}{ Table S1 } & $\begin{array}{l}\text { Tabulation of analytical techniques, methods, procedures and radiological } \\
\text { detection limits (RDL) for each radioisotope analyze }\end{array}$ & S6 \\
\hline & Materials & S7-S9 \\
\hline Figure S4 & $\begin{array}{l}\text { EPR spectrum of the aqueous solution of the dissolved precipitate obtained } \\
\text { from the reaction of }\left[\mathrm{fac}-\mathrm{Tc}(\mathrm{CO})_{3}(\mathrm{OH})\right]_{4} \text { with } \mathrm{NOBF}_{4}\end{array}$ & S8 \\
\hline Table S2 & $\begin{array}{l}\text { Organic chelators found in the AN-102 supernatant and their complexes with } \\
{\left[\mathrm{fac}_{-} \mathrm{Tc}(\mathrm{CO})_{3}\right]^{+}}\end{array}$ & S9 \\
\hline Sections S2 & Results & S10-S15 \\
\hline Tables S3A, B & $\begin{array}{l}\text { Selected Constituents of the 241-AN-102 Hanford Tank Waste Fractions } \\
\text { Determined in this Work. }\end{array}$ & S11-S12 \\
\hline Figure S5 & Tc K-edge XANES spectra for the various model Tc complexes & S13 \\
\hline Figure S6 & EPR spectrum collected on as-received AN-102 tank waste at $2.6 \mathrm{~K}$ & S14 \\
\hline Figure S7 & EPR spectrum collected on Cs-depleted AN-102 tank waste at $2.5 \mathrm{~K}$ & S15 \\
\hline & References & S16 \\
\hline
\end{tabular}




\section{SECTION S1: DETAILED EXPERIMENTAL SECTION}

\section{Instruments and procedures.}

Inductively Coupled Plasma (ICP) Analysis. Solutions were analyzed using a PerkinElmer 8300DV inductively coupled plasma-optical emission spectrometer. High-purity calibration standards were used to generate calibration curves and a separate standard source was used to verify continuing calibration during the analytical run. Serial dilutions were made to investigate and correct for matrix interferences.

Analysis of trace elements was performed using a PerkinElmer ELAN DRC-II inductively coupled plasmamass spectrometer. High-purity calibration standards were used to generate calibration curves and a separate standard source used to verify continuing calibration during the analytical run. Samples were prepared at a 2000x dilution due to high salt matrix. Serial dilutions were made to investigate and correct for matrix interferences.

Potentiometric titration. To determine the $\mathrm{OH}^{-}$concentration of the AN-102 supernatant fractions, potentiometric titrations were performed on the as-received fraction using a Metrohm titrator. A $2.5 \mathrm{x}$ dilution of each fraction was achieved by diluting $4 \mathrm{~mL}$ of the sample to $10 \mathrm{~mL}$ in $0.2 \mathrm{M}$ ammonium oxalate, and an aliquot of the diluted solution was titrated against $0.092 \mathrm{M} \mathrm{HCl}$.

Total Carbon Analysis (TOC). TOC was measured first with additions of heated sulfuric acid followed by the addition of a silver catalyzed acidic potassium persulfate solution for oxidation at 92 to $95{ }^{\circ} \mathrm{C}$. Samples were analyzed in duplicate. The calibration and quality control (QC) sample standards for the TOC initial/continuing calibration verification check (ICV/CCV) sample used was a $1000 \mu \mathrm{g} / \mathrm{mL}$ solution of total organic carbon standard. The calibration and QC sample standards for the TIC initial/continuing calibration verification check (ICV/CCV) sample was a $1000 \mu \mathrm{g} / \mathrm{mL}$ total inorganic standard. The QC samples analyzed as part of the method included initial and continuing calibration verification samples (ICV/CCV), initial and continuing calibration blanks (ICB/CCB), laboratory duplicates for each sample, a laboratory control sample/blank spike (LCS/BS), and an analytical spike. The work was performed in one batch. Two blanks were run at the beginning of each batch and after ICV/CCV to ensure that they were less than the EQL.

Nuclear Magnetic Resonance (NMR) Spectroscopy. The solution aliquots used for ${ }^{99} \mathrm{Tc}$ NMR analyses were placed in capped polytetrafluoroethylene (PTFE)/fluorinated ethylene propylene (FEP) copolymer sleeves (Wilmad Lab Glass, Vineland, NJ), which were then inserted into 10-mm glass NMR tubes to provide secondary containment for the radioactive liquid (shown in Figure S1). ${ }^{99} \mathrm{Tc}$ NMR data were routinely collected at $67.565 \mathrm{MHz}$ on a Tecmag Discovery spectrometer equipped with a 10-mm broadband Nalorac probe as described previously. ${ }^{1}$ A solution containing $10 \mathrm{mM} \mathrm{TcO}_{4}^{-}$was used as a ${ }^{99} \mathrm{Tc}$ chemical shift reference, and all chemical shift data are reported relative to $\mathrm{TcO}_{4}^{-} .^{2}$ The $10 \mathrm{mM} \mathrm{TcO}_{4}{ }^{-}$standard was also used as a quantification standard for an unknown $\mathrm{TcO}_{4}^{-}$species, while for any non- $\mathrm{TcO}_{4}^{-}$an appropriate $\mathrm{Tc}(\mathrm{I})$ or $\mathrm{Tc}(\mathrm{V})$ species was used.

${ }^{13} \mathrm{C}$ NMR measurements of radiological samples were performed on the same instrument, at $75.468 \mathrm{MHz}$. Spectra were referenced to a solution of ammonium carbonate (external standard) and compared to a control solution containing $1 \mathrm{M}$ ammonium carbonate in DI water. ${ }^{13} \mathrm{C}$ NMR measurements of non-radiological samples were performed on a Varian VNMRS spectrometer operating at a field strength of $11.7 \mathrm{~T}\left({ }^{1} \mathrm{H} v_{0}=\right.$ $500 \mathrm{MHz},{ }^{13} \mathrm{C} v_{0}=125 \mathrm{MHz}$ ) with a Varian $5-\mathrm{mm}$ direct, broadband tunable probe. Broadband ${ }^{1} \mathrm{H}$ decoupling using the WALTZ-16 composite pulse scheme was applied during acquisition of spectra only. Spectra were referenced using the ${ }^{13} \mathrm{C}$ signal of acetone- $\mathrm{D}_{8}$ contained in a coaxial insert, which also provided a lock signal. Processing was performed using VNMRJ 4.0 and Mestrenova 10.0. 


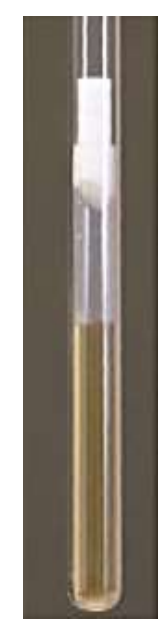

Figure S1. NMR solution samples placed in PTFE/FEP sleeves inserted into glass tubes

Electron paramagnetic resonance (EPR) spectroscopy. EPR spectra were acquired on a Bruker EMX Spectrometer equipped with an ER4102ST resonator (spectra at room temperature and $120 \mathrm{~K}$ ) or an ER4116DM Dual Mode resonator (spectra at 5 K) and an Oxford ESR910 cryostat. Samples were doubly contained by employing unbreakable FEP tube liners (Wilmad Lab Glass, Vineland, NJ) inside traditional quartz EPR tubes. Liquid samples employed $1.5 \mathrm{~mm}$ inner diameter (ID) liners and $4 \mathrm{~mm}$ outer diameter (OD) quartz tubes while frozen solution and powder samples used $3.15 \mathrm{~mm}$ ID liners and $5 \mathrm{~mm}$ OD tubes.

Fourier Transform Infrared (IR) Spectroscopy. Fourier transform infrared spectroscopy measurements were conducted using a spectrometer (ALPHA model, Bruker Optics) operated with OPUS software (Version 6.5 Build 6.5.92). Samples were measured directly on a diamond attenuated total reflectance (ATR) cell. For each sample, 24 scans with a resolution of 4 wavenumbers $\left(\mathrm{cm}^{-1}\right)$ were averaged to give the final spectrum. A background of ambient air was used for all samples. A sample volume of approximately $10 \mu \mathrm{L}$ was used for each analysis; this was adequate to cover the collection region of the ATR cell.

${ }^{99}$ Technetium X-ray Absorption Spectroscopy (XAS). XAS data were obtained either at SSRL BL 11-2 or at APS BL 12-BM in fluorescence or transmission mode. XAS data were obtained from $200 \mathrm{eV}$ below the Tc edge to $1000 \mathrm{eV}$ above the edge. Transmission data were obtained using Ar-filled ion chambers. Spectra were collected using a 13-element Ge detector and were corrected for detector dead time. For the data collected at SSRL, the data from $75 \mathrm{eV}$ below the edge to $200 \mathrm{eV}$ above the edge were obtained with $0.5-\mathrm{eV}$ spacing. The rest of the data points were widely spaced $(50 \mathrm{eV})$ and were used for the pre- and postedge correction. The monochromator was detuned $50 \%$ to reduce the harmonic content of the beam. Data were converted from raw data to spectra using SIXPack. ${ }^{3}$ Spectra were normalized using Artemis. ${ }^{4}$ Normalized XANES spectra were fit using standard spectra in the locally written program "fites." XANES standard spectra were carefully energy calibrated using $\mathrm{TcO}_{4}{ }^{-}$adsorbed on Reillex-HPQ as the energy reference.

A detailed description of the sample holders for XAS measurements. Two different sets of holders and configurations were used, one set for liquid samples and the other for solid samples. 
Containment for liquid samples: The liquid samples were confined within tube liners manufactured from FEP (fluorinated ethylene polypropylene copolymer) obtained from Wilmad lab glass. The tube liners had a factory-sealed round bottom, suited provide a contamination-free environment when the analytes contain organic solvents (dichloromethane, concentrated hydroxide solutions). Tubes of $1.3 \mathrm{~mm}$ inner diameter, and $2.25 \mathrm{~mm}$ outer diameter were used, and the total length of the tubes were cut to $18 \mathrm{~mm}$. Of that, $6 \mathrm{~mm}$ was used for the sample solution, amounting to a total sample volume of $\sim 8 \mu \mathrm{L}$. $2 \mathrm{~mm}$ of empty head space was left over the sample solution. Subsequently, a $10 \mathrm{~mm}$ polytetrafluoroethylene (PTFE) cap was secured with epoxy at the mouth of the tube to seal the tube off, as shown in Figure S2(a). This served as the first level of confinement barrier.

Each of these tubes ( 3 total per plate) were inserted within elliptical cavities ( $19 \mathrm{~mm}$ x $3 \mathrm{~mm}$ ) on a Teflon plate as shown in Figure S2(b). The cavities were be surrounded by a layer of viton O-ring as an additional measure to ensure contamination free environment. The Teflon plate was be placed between two Kapton layers, and the cell was surrounded by stainless steel plates which will be sealed off using screws as shown in Figure S2(c). This will serve as the second level of confinement barrier. This entire sealed cell will be placed within two Kapton layers separated by an outer Teflon spacer and flat o-rings, and sealed off using another two stainless steel plates, as shown in Figure S2(d). This provided a precautionary third level of confinement barrier. The cells in Figure S2(b, c) each measured at $4 \mathrm{~cm} \times 3.5 \mathrm{~cm}$. Four of these were assembled together in a combination cell shown in Figure $\mathbf{S 2}(\mathbf{d})$ with dimensions $9 \mathrm{~cm} \mathrm{x} 8 \mathrm{~cm}$. The samples placed within the triple containment were be attached to a Thorlab kinematic base used at the APS and manipulated for placement in the beam path.

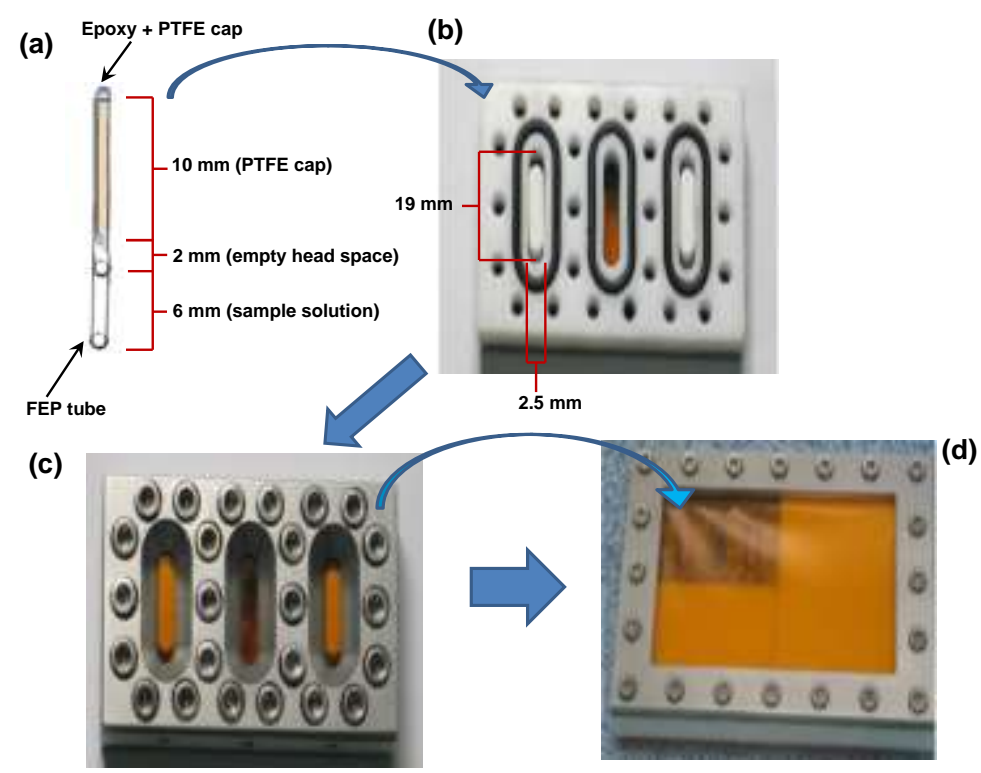

Figure S2. Design of the triple containment XAS cell for liquid samples: (a) FEP liner equipped with PTFE caps for primary containment of liquid samples, (b) Teflon plate with elliptical cavities for positioning and securing the FEP liners, (c) internal stainless steel plates to secure the Teflon plate placed between two Kapton layers as secondary containment, (d) external assembly to secure the internal secondary containment assembly and act as the third layer of containment; it consists of the internal assembly to be placed within two Kapton layers separated by an outer Teflon spacer and flat o-rings, and sealed off using another two stainless steel plates. 
Containment for solid samples: The dry, solid samples were confined through double layer containment. The samples were loaded into teflon holders shown in Figure S3(a) and enclosed on either side by Kapton tape. A second layer of tape, this time mylar, will be places over the Kapton (Figure S3(b)). These samples were then be taped to an aluminum holder (Figure S3(c)). This holder was then be placed into a hot seal bag, where the edges were sealed, and the seal was taped over with Kapton tape (Figure S3(d)).

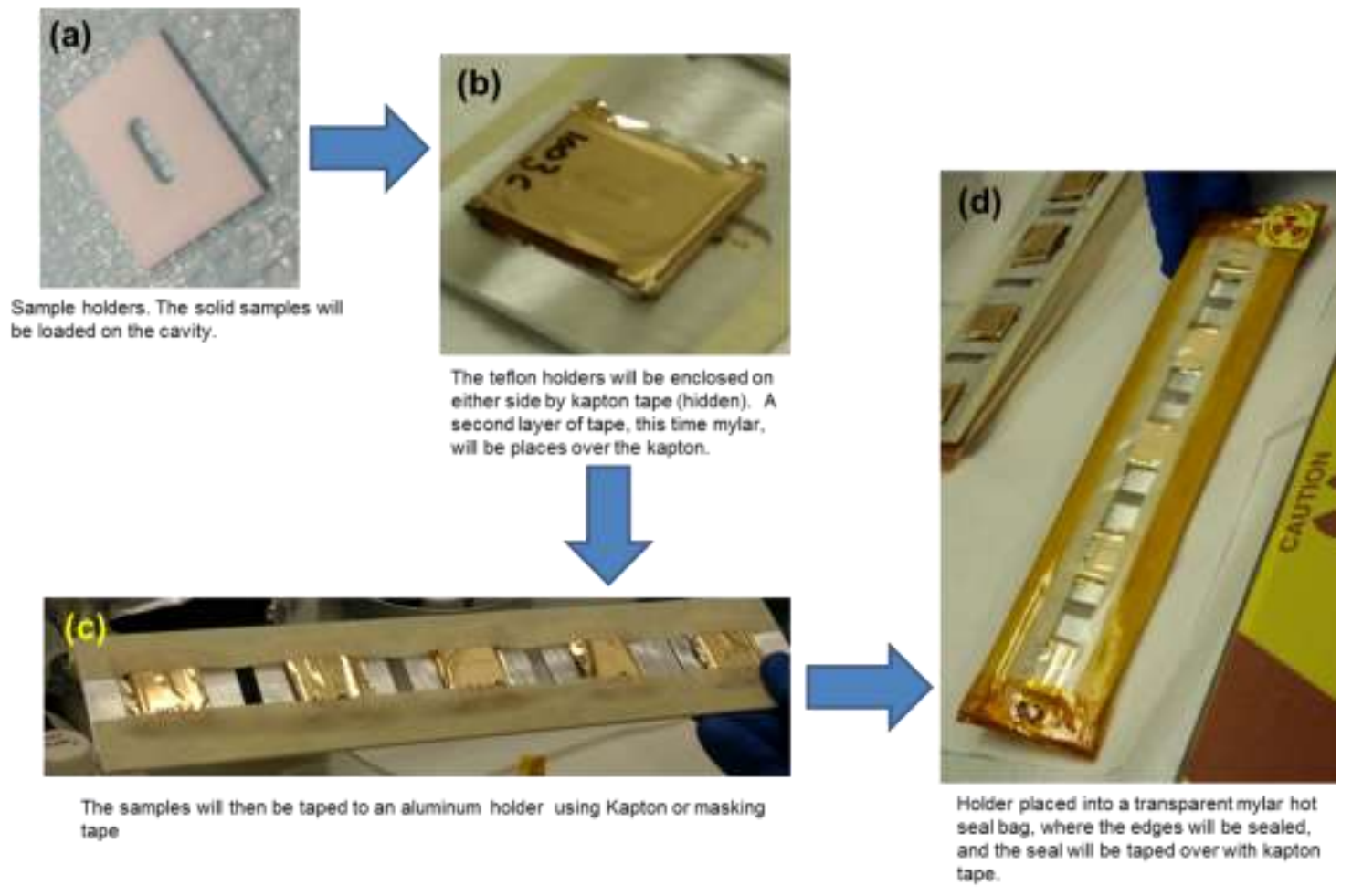

Figure S3. Design of the triple containment XAS cell for solid samples: (a) Teflon holders for solid samples, (b) the sample loaded holders wrapped by a first layer of Kapton (hidden) and a second layer of mylar tape on all sides, (c) the individual wrapped holders mounted on an aluminum holder frame using masking tape, (d) the aluminum frame wrapped inside a transparent mylar hot seal bag with sealed edges that are secured with Kapton tape. 
Radiochemistry. The radiochemistry studies were conducted at GEL Laboratories, LLC, Charleston, SC. The analysis techniques, methods, procedures and radiological detection limits (RDL) are given in Table S1. For ${ }^{99} \mathrm{Tc}$, the subsequent analyses involved the use of a ${ }^{99 \mathrm{~m}} \mathrm{Tc}$ isotopic tracer for the determination of the chemical yield and the analysis of ${ }^{99} \mathrm{Tc}$ with liquid scintillation counting.

Table S1. Tabulation of analysis techniques, methods, procedures and radiological detection limits (RDL) for each radioisotope analyzed

\begin{tabular}{|c|c|c|c|c|c|c|}
\hline Isotope & Technique & Analytical method & Procedure & $\begin{array}{l}\text { RDL } \\
(\mathbf{C i} / \mathbf{L})\end{array}$ & RDL(M) & $\begin{array}{c}\text { RDL } \\
\text { (ug/L) }\end{array}$ \\
\hline Am-241 & Alpha & $\begin{array}{l}\text { DOE EML HASL-300, } \\
\text { Am-05-RC Modified }\end{array}$ & GL-RAD-A-011 REV\# 26 & $1.0 \mathrm{E}-12$ & $1.3 \mathrm{E}-15$ & $3.1 \mathrm{E}-07$ \\
\hline Co-60 & Gamma & EPA 901.1 & GL-RAD-A-013 REV\# 27 & $1.0 \mathrm{E}-11$ & $1.5 \mathrm{E}-16$ & $9.1 \mathrm{E}-09$ \\
\hline Cs-137 & Gamma & EPA 901.1 & GL-RAD-A-013 REV\# 27 & $1.0 \mathrm{E}-11$ & $8.3 \mathrm{E}-16$ & $1.1 \mathrm{E}-07$ \\
\hline Eu-154 & Gamma & EPA 901.1 & GL-RAD-A-013 REV\# 27 & $1.0 \mathrm{E}-11$ & $4.3 \mathrm{E}-16$ & $6.7 \mathrm{E}-08$ \\
\hline Sr-90 & $\begin{array}{l}\text { Gas Flow } \\
\text { Proportional } \\
\text { Counting with } \\
\text { Sr carrier }\end{array}$ & $\begin{array}{l}\text { EPA } 905.0 \\
\text { Modified/DOE RP501 } \\
\text { Rev. } 1 \text { Modified }\end{array}$ & GL-RAD-A-004 REV\# 19 & $2.0 \mathrm{E}-12$ & $1.5 \mathrm{E}-16$ & $1.3 \mathrm{E}-08$ \\
\hline Tc-99 & $\begin{array}{l}\text { Liquid } \\
\text { Scintillation } \\
\text { Counting with } \\
\text { Tc-99m tracer }\end{array}$ & $\begin{array}{l}\text { DOE EML HASL-300, } \\
\text { Tc-02-RC Modified }\end{array}$ & GL-RAD-A-059 REV\# 5 & $5.0 \mathrm{E}-11$ & 3.0E-11 & 2.9E-03 \\
\hline $\mathrm{U}-238$ & Alpha & $\begin{array}{l}\text { DOE EML HASL-300, } \\
\text { U-02-RC }\end{array}$ & GL-RAD-A-011 REV\# 26 & $1.0 \mathrm{E}-12$ & $1.3 \mathrm{E}-08$ & $3.0 \mathrm{E}+00$ \\
\hline
\end{tabular}




\section{Materials}

$\mathrm{NH}_{4} \mathrm{TcO}_{4}$ stock available in-house at the Radiochemical Processing Laboratory (RPL) at PNNL was used. Diglyme, acetonitrile, diethyl ether, dichloromethane, and borane-tetrahydrofuran $\mathrm{BH}_{3} / \mathrm{THF}$ complex were obtained from Sigma-Aldrich and used without further purification. $\mathrm{Tc}(\mathrm{V})$ containing species $\left(\mathrm{Bu}_{4} \mathrm{~N}\right)\left[\mathrm{TcOCl}_{4}\right]$ was obtained via literature procedures. ${ }^{5-7}$ Argon gas was obtained from Matheson. Diethyl ether (ACS reagent, anhydrous, $\geq 99 \%$ ) and acetonitrile (anhydrous, 99.8\%) were purchased from SigmaAldrich. Toluene [Certified ACS, $(\geq 99.5 \%)$ ] was purchased from Fisher Scientific. All aqueous solutions were prepared using distilled water deionized to $>18 \mathrm{M} \Omega-\mathrm{cm}$ with a Barnstead Nanopure water purification system.

Preparation of simulant solutions. A simple simulant solution was used for ${ }^{31} \mathrm{P}$ experiments that consisted of a mixture of $3 \mathrm{M} \mathrm{NaNO}_{3}$ and $0.4 \mathrm{M} \mathrm{NaOH}$ to which the required ligands were added.

\section{Synthesis of reference compounds:}

Synthesis of Tc(I) species: The starting complexes $\left(\mathrm{Et}_{4} \mathrm{~N}\right)_{2}\left[f a c-\mathrm{Tc}(\mathrm{CO})_{3} \mathrm{Cl}_{3}\right]$ and $\left[f a c-\mathrm{Tc}(\mathrm{CO})_{3}(\mathrm{OH})\right]_{4}$ were obtained via literature procedures, ${ }^{8-9}$ from which the $\left[\mathrm{fac}-\mathrm{Tc}(\mathrm{CO})_{3}\right]^{+}$containing aqua species of the general formula $\left[f a c-\mathrm{Tc}(\mathrm{CO})_{3}\left(\mathrm{H}_{2} \mathrm{O}\right)_{3-\mathrm{n}}(\mathrm{OH})_{\mathrm{n}}\right]^{1-\mathrm{n}}(\mathrm{n}=0-3)$ were generated by dissolving $\left(\mathrm{Et}_{4} \mathrm{~N}\right)_{2}\left[\mathrm{fac}-\mathrm{Tc}(\mathrm{CO})_{3} \mathrm{Cl}_{3}\right]$ or $\left[\mathrm{fac}-\mathrm{Tc}(\mathrm{CO})_{3}(\mathrm{OH})\right]_{4}$ in $5 \mathrm{M} \mathrm{NaNO}_{3}$ containing variable $\mathrm{NaOH}$ concentrations. ${ }^{8-9}$ The chelate complexes of the general formulae $\left[f a c-\mathrm{Tc}(\mathrm{CO})_{3}(\mathrm{~L})_{\mathrm{x}}\right]^{\mathrm{n}-}$ with various polydentate polyhydroxycarboxylate (e.g.: gluconate) or polyaminocarboxylates (e.g.: iminodiacetate (IDA), 2, 2', 2"-nitrolotriacetate (NTA), 2,2',2",2"'-(Ethane-1,2-diyldinitrilo)tetraacete (EDTA), N-(2-Hydroxyethyl)ethylenediamine-N,N',N'triacetate (HEDTA), 2-[Bis[2-[bis(carboxymethyl)amino]ethyl]amino]acetate (DTPA)) ligands were prepared according to literature procedure. ${ }^{10-12}$ The coordination of different chelators to $\left[\mathrm{fac}-\mathrm{Tc}(\mathrm{CO})_{3}\right]^{+}$are determined by ${ }^{99} \mathrm{Tc}$ NMR based on variations in the chemical shift compared to $\left[\mathrm{fac}-\mathrm{Tc}(\mathrm{CO})_{3}\right]^{+}$species due to the formation of the $\left[\mathrm{fac}-\mathrm{Tc}(\mathrm{CO})_{3}(\mathrm{~L})_{\mathrm{x}}\right]^{\mathrm{n}-}$ product. ${ }^{12-13}$ These species in aqueous solutions were used as $\left[\text { fac }-\mathrm{Tc}(\mathrm{CO})_{3}\right]^{+}$reference standards for ${ }^{99} \mathrm{Tc} \mathrm{NMR}$ and XAS measurements.

Synthesis of Tc(II) species: $\left[\mathrm{fac}-\mathrm{Tc}(\mathrm{CO})_{3}(\mathrm{OH})\right]_{4}$ was treated with the nitrosyl donor $\mathrm{NOBF}_{4}$ in chlorinated organic solvent $\mathrm{CH}_{2} \mathrm{Cl}_{2}$ following a modified literature procedure. ${ }^{14-15}$ About $0.02 \mathrm{~g}$ of $\left[\mathrm{fac}-\mathrm{Tc}(\mathrm{CO})_{3}(\mathrm{OH})\right]_{4}$ was dissolved in $5 \mathrm{~mL} \mathrm{CH}_{2} \mathrm{Cl}_{2}$, to which $0.05 \mathrm{~g}$ solid $\mathrm{NOBF}_{4}$ was added. The inhomogeneous mixture was stirred for 7 days. Over time the solution changed color from off-white to yellow, which was accompanied by the formation of a yellow precipitate. This was separated from the solution by decantation and washed with $\mathrm{CH}_{2} \mathrm{Cl}_{2}$. Dissolution of the solid in aqueous solution (water or $5 \mathrm{M} \mathrm{NaNO}_{3}$ ) resulted in a solution that changed color from yellow to red within 30 minutes. ${ }^{99} \mathrm{Tc}$ NMR spectrum of the resultant solution did not show the presence of any NMR active Tc species. An EPR analysis of the red water solution showed a series of 10 resonances, a system characteristic of $\mathrm{Tc}$ (II) with $\mathrm{S}=1 / 2, \mathrm{I}=9 / 2$ (Figure S2). This is indicative of oxidation of the $\mathrm{Tc}(\mathrm{I})$ center in water, resulting in the generation of an evenly charged paramagnetic species presumably of the formula $\left[\mathrm{Tc}(\mathrm{CO})_{2}(\mathrm{NO})\right]^{\mathrm{n}+}$. 


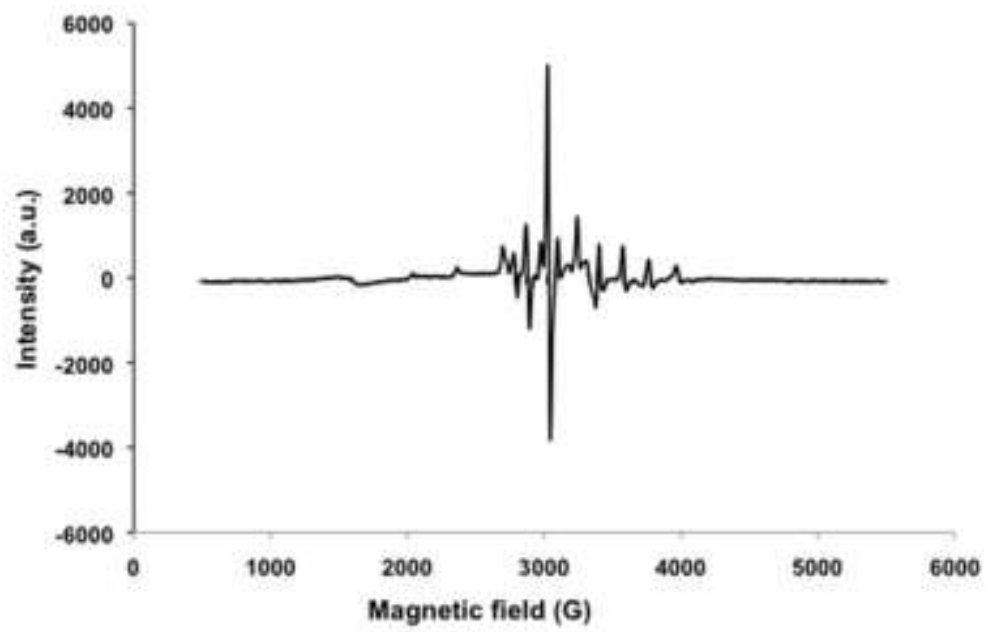

Figure S4. EPR spectrum of the aqueous solution of the dissolved precipitate obtained from the reaction of $\left[\text { fac- } \mathrm{Tc}(\mathrm{CO})_{3}(\mathrm{OH})\right]_{4}$ with $\mathrm{NOBF}_{4}$ 
Table S2. Organic chelators found in the AN-102 supernatant (taken from Urie et al. 2002 ${ }^{16}$ ) and their complexes with $\left[\mathrm{fac}-\mathrm{Tc}(\mathrm{CO})_{3}\right]^{+}$(taken from Levitskaia et al. 2015 ${ }^{12}$ )

\begin{tabular}{|c|c|c|c|c|}
\hline \multirow{2}{*}{$\begin{array}{l}\text { Organic } \\
\text { chelator }\end{array}$} & \multicolumn{2}{|c|}{$\begin{array}{l}\text { Concentration of chelator in AN- } \\
102 \text { supernatant }^{16}\end{array}$} & \multicolumn{2}{|c|}{$\begin{array}{c}\text { Coordination to }\left[\mathrm{fac}-\mathrm{Tc}(\mathrm{CO})_{3}\right]^{+} \\
\text {observed by }{ }^{99} \mathrm{Tc} \mathrm{NMR}^{12}\end{array}$} \\
\hline & $\mu \mathrm{g} \mathrm{mL} L^{-1}$ & $\mathrm{mM}$ & Complex formed & Chemical shift, ppm \\
\hline Citrate & 4,400 & 23 & $\mathrm{~N}$ & NA \\
\hline EDTA & 420 & 1.4 & $\mathrm{Y}$ & -915 \\
\hline Formate & 8,000 & 180 & $\mathrm{~N}$ & NA \\
\hline Gluconate & 1,000 & 5.1 & $\mathrm{Y}$ & $-1110,-1232,-1253$ \\
\hline Glycolate & 10,500 & 140 & $\mathrm{~N}$ & NA \\
\hline HDEHP & 0.5 & 0.0016 & $\mathrm{~N}$ & NA \\
\hline HEDTA & 100 & 0.53 & $\mathrm{~N}$ & NA \\
\hline IDA & 2,500 & 19 & $\mathrm{Y}$ & -1000 \\
\hline NTA & 190 & 0.10 & $\mathrm{Y}$ & -914 \\
\hline Succinate & 36 & 0.31 & $\mathrm{~N}$ & NA \\
\hline
\end{tabular}




\section{SECTION S2: RESULTS}

\section{AN-102 tank waste processing and analytical characterization}

The recovery of each elemental constituent was calculated based on the analysis of both "as received" and "Na-adjusted" fractions. The elemental analysis indicates the "as received" AN-102 supernatant to be primarily comprised of alkali metals (Na being the dominant component, along with smaller quantities of $\mathrm{K}$ and $\mathrm{Cs}$ ), group III metals with aluminum being the second primary constituent, alkaline earth metals (Ca and Sr). Among the other components, all anions demonstrated good to excellent recovery based on the "as received" fractions. Among anions, $\mathrm{NO}_{3}{ }^{-}$at $3.12 \mathrm{M}$ is the most abundant followed by $\mathrm{NO}_{2}{ }^{-}(2.05 \mathrm{M})$ and $\mathrm{Cl}^{-}(0.115 \mathrm{M})$. The supernatant is highly alkaline with free $\mathrm{OH}^{-}$at $0.39 \mathrm{M}$. Sulfur and phosphorus were also present in appreciable quantities, respectively, in which the oxyanions $\mathrm{SO}_{4}{ }^{2-}$ and $\mathrm{PO}_{4}{ }^{3-}$ are among key contributors. It is worth noting that the total amounts of sulfur $(0.175 \mathrm{M})$ and phosphorus $(0.049 \mathrm{M})$ were observed to be slightly higher in concentrations than sulfate $(0.148 \mathrm{M})$ and phosphate $(0.047 \mathrm{M})$ anions. The slightly lower molar concentration of phosphate compared to the amount of phosphorus is presumably suggestive of other forms of phosphorus; this is supported by the observation of Urie et al. who had determined presence of organo-phosphates in AN-102. ${ }^{16}$ It is also likely that similar presence of organosulfur species may be a factor contributing to the discrepancy between the concentrations of sulfur observed by ICP-OES and anionic sulfate observed by IC.

Overall, analytical recovery was observed to be satisfactory for majority of constituents, while it was excellent for the most abundant waste constituents including $\mathrm{Na}, \mathrm{Al}$ and $\mathrm{K}$. Na concentration in "asreceived" supernatant was found to be $10.8 \mathrm{M}$. Adjustment of the Na concentration by dilution resulted in the 5.6 M Na concentration in the "Na-adjusted" fraction. This concentration was slightly lowered (5.48 $\mathrm{M})$ in the Cs-depleted fraction, suggesting that a small $\mathrm{Na}$ fraction was retained by sRF resin. This was supported by analysis of the "column strip", proving excellent overall recovery for $\mathrm{Na}$. Al showed a concentration of $0.53 \mathrm{M}$ in the "as received" fraction, which changed to $0.23 \mathrm{M}$ upon dilution leading to the "Na-adjusted" fraction. Like $\mathrm{Na}$, a small retention of $\mathrm{Al}$ by the sRF was observed. Overall, the Al recovery was excellent based on the "as received" fraction, while it was slightly overestimated based on the "Na-adjusted" fraction. Likewise, $\mathrm{K}$ also showed a similar trend, demonstrating excellent recovery for the "as received" fraction, while being slightly underestimated based on the "Na-adjusted" fraction. 
Table S3A. Selected Constituents of the 241-AN-102 Hanford Tank Waste Fractions Determined in this Work. (NM is not measured. ND is not detected.)

\begin{tabular}{|c|c|c|c|c|c|c|c|c|c|c|c|c|c|}
\hline \multirow[b]{2}{*}{ Component } & \multirow[b]{2}{*}{$\begin{array}{l}\text { Analytical } \\
\text { Method }\end{array}$} & \multicolumn{2}{|c|}{ AN-102 As Received } & \multicolumn{2}{|c|}{ AN-102 Na Adjusted } & \multicolumn{2}{|c|}{$\begin{array}{c}\text { AN-102 sRF Column } \\
\text { Strip }\end{array}$} & \multicolumn{2}{|c|}{ AN-102 Cs Depleted } & \multicolumn{2}{|c|}{ EQL } & \multirow{2}{*}{$\begin{array}{c}\text { \% Recov. } \\
\text { As Rec. }\end{array}$} & \multirow{2}{*}{\begin{tabular}{|c|}
$\begin{array}{c}\% \\
\text { Recov. }\end{array}$ \\
$\mathrm{Na}$ \\
Adj.
\end{tabular}} \\
\hline & & $\begin{array}{l}\text { Conc. } \\
(\mu \mathrm{g} / \mathrm{L})\end{array}$ & $\begin{array}{l}\text { Conc. } \\
\text { (M) }\end{array}$ & $\begin{array}{l}\text { Conc. } \\
(\mu \mathrm{g} / \mathrm{L})\end{array}$ & Conc. (M) & $\begin{array}{l}\text { Conc. } \\
(\mu \mathrm{g} / \mathrm{L})\end{array}$ & Conc. (M) & $\begin{array}{l}\text { Conc. } \\
(\mu \mathrm{g} / \mathrm{L})\end{array}$ & $\begin{array}{l}\text { Conc. } \\
\text { (M) }\end{array}$ & $\begin{array}{l}\text { Conc. } \\
(\mu \mathrm{g} / \mathrm{L})\end{array}$ & $\begin{array}{l}\text { Conc. } \\
\text { (M) }\end{array}$ & & \\
\hline \multicolumn{14}{|c|}{ Bulk Salt Constituents } \\
\hline $\mathrm{Na}$ & ICP-OES & $2.5 \mathrm{E}+08$ & $1.1 \mathrm{E}+01$ & $1.4 \mathrm{E}+08$ & $6.1 \mathrm{E}+00$ & $4.4 \mathrm{E}+06$ & $1.9 \mathrm{E}-01$ & $1.3 \mathrm{E}+08$ & $5.5 \mathrm{E}+00$ & $4.5 \mathrm{E}+05$ & $1.9 \mathrm{E}-02$ & $102 \%$ & $97 \%$ \\
\hline $\mathrm{Al}$ & ICP-OES & $1.4 \mathrm{E}+07$ & $5.3 \mathrm{E}-01$ & $6.2 \mathrm{E}+06$ & $2.3 \mathrm{E}-01$ & $7.5 \mathrm{E}+04$ & $2.8 \mathrm{E}-03$ & $7.0 \mathrm{E}+06$ & $2.6 \mathrm{E}-01$ & $1.7 \mathrm{E}+04$ & $6.1 \mathrm{E}-04$ & $95 \%$ & $118 \%$ \\
\hline K & ICP-OES & $2.4 \mathrm{E}+06$ & $6.0 \mathrm{E}-02$ & $1.4 \mathrm{E}+06$ & $3.7 \mathrm{E}-02$ & $2.3 \mathrm{E}+05$ & $5.9 \mathrm{E}-03$ & $7.5 \mathrm{E}+05$ & $1.9 \mathrm{E}-02$ & $1.6 \mathrm{E}+05$ & 4.1E-03 & $95 \%$ & $84 \%$ \\
\hline \multicolumn{14}{|c|}{ Anions } \\
\hline $\mathrm{NO}_{3}{ }^{-}$ & IC & $1.9 \mathrm{E}+08$ & $3.1 \mathrm{E}+00$ & $1.4 \mathrm{E}+08$ & $2.2 \mathrm{E}+00$ & $1.7 \mathrm{E}+07$ & $2.7 \mathrm{E}-01$ & $9.4 \mathrm{E}+07$ & $1.5 \mathrm{E}+00$ & $5.0 \mathrm{E}+03$ & $8.1 \mathrm{E}-02$ & $99 \%$ & $93 \%$ \\
\hline $\mathrm{NO}_{2}^{-}$ & IC & $9.5 \mathrm{E}+07$ & $2.1 \mathrm{E}+00$ & $6.6 \mathrm{E}+07$ & $1.4 \mathrm{E}+00$ & ND & ND & $4.9 \mathrm{E}+07$ & $1.1 \mathrm{E}+00$ & $5.0 \mathrm{E}+03$ & $1.1 \mathrm{E}-01$ & & $75 \%$ \\
\hline Free $\mathrm{OH}^{-}$ & titration & & $3.9 \mathrm{E}-01$ & \multicolumn{6}{|c|}{ ND } & & $1.0 \mathrm{E}-4$ & NA & NA \\
\hline$S$ & ICP-OES & $5.6 \mathrm{E}+06$ & $1.8 \mathrm{E}-01$ & $3.7 \mathrm{E}+06$ & $1.2 \mathrm{E}-01$ & ND & ND & $2.8 \mathrm{E}+06$ & $8.8 \mathrm{E}-02$ & $4.8 \mathrm{E}+04$ & $1.5 \mathrm{E}-03$ & $96 \%$ & $78 \%$ \\
\hline $\mathrm{Cl}^{-}$ & ICP-OES & $4.1 \mathrm{E}+06$ & $1.2 \mathrm{E}-01$ & ND & ND & ND & ND & ND & ND & $2.5 \mathrm{E}+03$ & $7.1 \mathrm{E}-02$ & $\mathrm{NA}$ & NA \\
\hline $\mathrm{P}$ & ICP-OES & $1.5 \mathrm{E}+06$ & $4.9 \mathrm{E}-02$ & $1.2 \mathrm{E}+06$ & $3.8 \mathrm{E}-02$ & ND & ND & $9.2 \mathrm{E}+05$ & $3.0 \mathrm{E}-02$ & $4.1 \mathrm{E}+04$ & $1.3 \mathrm{E}-03$ & $115 \%$ & $79 \%$ \\
\hline \multicolumn{14}{|c|}{ Carbon } \\
\hline Inorg. C & TIC & $1.3 \mathrm{E}+07$ & $1.1 \mathrm{E}+00$ & $6.3 \mathrm{E}+06^{(\mathrm{a})}$ & & NM & NM & $6.9 \mathrm{E}+06$ & 5.8E-01 & & $1.0 \mathrm{E}-4$ & $101 \%$ & NA \\
\hline Org. C & TOC & $2.3 \mathrm{E}+07$ & $2.0 \mathrm{E}+00$ & $1.2 \mathrm{E}+07^{(\mathrm{a})}$ & & NM & NM & $1.2 \mathrm{E}+07$ & $1.0 \mathrm{E}+00$ & & $1.0 \mathrm{E}-4$ & $93 \%$ & NA \\
\hline
\end{tabular}

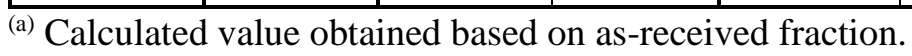


Table S3B. Selected Constituents of the 241-AN-102 Hanford Tank Waste Fractions Determined in this Work (continued). (NM is not measured. ND is not detected.)

\begin{tabular}{|c|c|c|c|c|c|c|c|c|c|c|c|c|c|}
\hline \multirow{2}{*}{ Component } & \multirow{2}{*}{$\begin{array}{l}\text { Analytical } \\
\text { Method }\end{array}$} & \multicolumn{2}{|c|}{ AN-102 As Received } & \multicolumn{2}{|c|}{ AN-102 Na Adjusted } & \multicolumn{2}{|c|}{$\begin{array}{c}\text { AN-102 sRF Column } \\
\text { Strip } \\
\end{array}$} & \multicolumn{2}{|c|}{ AN-102 Cs Depleted } & \multicolumn{2}{|c|}{ EQL } & \multirow{2}{*}{$\begin{array}{l}\text { \% Recov. } \\
\text { As Rec. }\end{array}$} & \multirow{2}{*}{$\begin{array}{c}\begin{array}{c}\% \\
\text { Recov. }\end{array} \\
\text { Na Adj. }\end{array}$} \\
\hline & & $\begin{array}{l}\text { Conc. } \\
(\mu \mathrm{g} / \mathrm{L})\end{array}$ & $\begin{array}{c}\text { Conc. } \\
\text { (M) }\end{array}$ & $\begin{array}{l}\text { Conc. } \\
(\mu \mathrm{g} / \mathrm{L})\end{array}$ & $\begin{array}{c}\text { Conc. } \\
\text { (M) }\end{array}$ & $\begin{array}{l}\text { Conc. } \\
(\mu \mathrm{g} / \mathrm{L})\end{array}$ & Conc. (M) & $\begin{array}{l}\text { Conc. } \\
(\mu \mathrm{g} / \mathrm{L})\end{array}$ & $\begin{array}{c}\text { Conc. } \\
\text { (M) }\end{array}$ & $\begin{array}{l}\text { Conc. } \\
(\mu \mathrm{g} / \mathrm{L})\end{array}$ & $\begin{array}{l}\text { Conc. } \\
\text { (M) }\end{array}$ & & \\
\hline \multicolumn{14}{|c|}{$p$-block, $d$-block and $f$-block metals } \\
\hline $\mathrm{Cr}$ & ICP-OES & $2.4 \mathrm{E}+05$ & 4.7E-03 & $1.3 \mathrm{E}+05$ & $2.6 \mathrm{E}-03$ & ND & ND & $1.2 \mathrm{E}+05$ & $2.4 \mathrm{E}-03$ & $2.3 E+03$ & $4.5 \mathrm{E}-05$ & $96 \%$ & $95 \%$ \\
\hline $\mathrm{Ni}$ & ICP-OES & $4.1 \mathrm{E}+05$ & 7.1E-03 & $2.7 \mathrm{E}+05$ & $4.6 \mathrm{E}-03$ & ND & ND & $2.1 \mathrm{E}+05$ & $3.6 \mathrm{E}-03$ & $1.4 \mathrm{E}+04$ & $2.4 \mathrm{E}-04$ & $98 \%$ & $80 \%$ \\
\hline $\mathrm{Pb}$ & ICP-OES & $1.6 \mathrm{E}+05$ & 7.7E-04 & $1.0 \mathrm{E}+05$ & $5.0 \mathrm{E}-04$ & ND & ND & $7.8 \mathrm{E}+04$ & $3.8 \mathrm{E}-04$ & $1.4 \mathrm{E}+04$ & $6.7 \mathrm{E}-05$ & $93 \%$ & $77 \%$ \\
\hline $\mathrm{Cd}$ & ICP-OES & $6.1 \mathrm{E}+04$ & $5.4 \mathrm{E}-04$ & $3.8 \mathrm{E}+04$ & $3.4 \mathrm{E}-04$ & ND & ND & $2.7 \mathrm{E}+04$ & $2.4 \mathrm{E}-04$ & $4.2 \mathrm{E}+03$ & $3.8 \mathrm{E}-05$ & $83 \%$ & $73 \%$ \\
\hline $\mathrm{Fe}$ & ICP-OES & $2.9 \mathrm{E}+04$ & $5.2 \mathrm{E}-04$ & $1.3 \mathrm{E}+04$ & $2.3 \mathrm{E}-04$ & ND & ND & ND & ND & $1.0 \mathrm{E}+04$ & $1.8 \mathrm{E}-04$ & NA & NA \\
\hline $\mathrm{Cu}$ & ICP-OES & $2.8 \mathrm{E}+04$ & 4.4E-04 & $1.6 \mathrm{E}+04$ & $2.6 \mathrm{E}-04$ & ND & ND & $1.2 \mathrm{E}+04$ & $1.9 \mathrm{E}-04$ & $7.9 \mathrm{E}+03$ & $1.2 \mathrm{E}-04$ & $84 \%$ & $77 \%$ \\
\hline $\mathrm{Mn}$ & ICP-OES & $1.3 \mathrm{E}+04$ & $2.4 \mathrm{E}-04$ & $2.3 \mathrm{E}+03$ & $4.2 \mathrm{E}-05$ & ND & ND & $3.9 \mathrm{E}+03$ & $7.0 \mathrm{E}-05$ & $2.4 \mathrm{E}+03$ & 4.4E-05 & $55 \%$ & $169 \%$ \\
\hline $\mathrm{Zn}$ & ICP-OES & $6.7 \mathrm{E}+03$ & $1.0 \mathrm{E}-04$ & $3.7 \mathrm{E}+03$ & $5.6 \mathrm{E}-05$ & ND & ND & ND & ND & $6.2 \mathrm{E}+03$ & $9.4 \mathrm{E}-05$ & NA & NA \\
\hline La-139 & ICP-MS & $1.3 \mathrm{E}+04$ & $9.6 \mathrm{E}-05$ & $6.4 \mathrm{E}+03$ & $4.6 \mathrm{E}-05$ & ND & ND & $6.3 \mathrm{E}+03$ & $4.5 \mathrm{E}-05$ & $2.8 \mathrm{E}+02$ & $2.0 \mathrm{E}-06$ & $89 \%$ & $100 \%$ \\
\hline Nd-146 & ICP-MS & $1.1 \mathrm{E}+04$ & 7.5E-05 & $4.9 \mathrm{E}+03$ & $3.4 \mathrm{E}-05$ & ND & ND & $4.7 \mathrm{E}+03$ & $3.2 \mathrm{E}-05$ & $2.3 \mathrm{E}+02$ & $1.6 \mathrm{E}-06$ & $82 \%$ & $98 \%$ \\
\hline Pr-141 & ICP-MS & $3.6 \mathrm{E}+03$ & $2.5 \mathrm{E}-05$ & $1.6 \mathrm{E}+03$ & $1.1 \mathrm{E}-05$ & ND & ND & $1.6 \mathrm{E}+03$ & $1.1 \mathrm{E}-05$ & $1.6 \mathrm{E}+02$ & $1.1 \mathrm{E}-06$ & $85 \%$ & $102 \%$ \\
\hline Ce-140 & ICP-MS & $2.3 \mathrm{E}+03$ & $1.6 \mathrm{E}-05$ & $8.9 \mathrm{E}+02$ & $6.3 \mathrm{E}-06$ & ND & ND & $9.7 \mathrm{E}+02$ & $6.9 \mathrm{E}-06$ & $2.1 \mathrm{E}+02$ & $1.5 \mathrm{E}-06$ & $80 \%$ & $111 \%$ \\
\hline $\begin{array}{l}\text { Ru-100, } \\
\text { Ru-101, } \\
\text { Ru-102, } \\
\text { Ru-104 }\end{array}$ & ICP-MS & $9.1 \mathrm{E}+04$ & $9.0 \mathrm{E}-04$ & $4.2 \mathrm{E}+04$ & $4.2 \mathrm{E}-04$ & $9.4 \mathrm{E}+01$ & $9.3 \mathrm{E}-07$ & $4.5 \mathrm{E}+04$ & $4.5 \mathrm{E}-04$ & $4.7 \mathrm{E}+03$ & 4.7E-05 & $94 \%$ & $110 \%$ \\
\hline \multicolumn{14}{|c|}{ Radionuclides } \\
\hline Sr-90 & GEA & $1.2 \mathrm{E}+03$ & $1.3 \mathrm{E}-05$ & $1.2 \mathrm{E}+02$ & $1.3 \mathrm{E}-06$ & $7.3 \mathrm{E}+00$ & $8.1 \mathrm{E}-08$ & $1.3 \mathrm{E}+09$ & $2.6 \mathrm{E}+02$ & $1.3 \mathrm{E}-08$ & $1.3 \mathrm{E}-14$ & $65 \%$ & $105 \%$ \\
\hline Tc-99 & ICP-MS & $8.4 \mathrm{E}+03$ & $8.5 \mathrm{E}-05$ & $5.7 \mathrm{E}+03$ & $5.8 \mathrm{E}-05$ & $6.4 \mathrm{E}+02$ & $6.4 \mathrm{E}-06$ & $4.8 \mathrm{E}+03$ & $4.8 \mathrm{E}-05$ & $3.3 \mathrm{E}+02$ & $3.3 \mathrm{E}-06$ & $133 \%$ & $88 \%$ \\
\hline Cs-133 & ICP-MS & $9.5 E+03$ & 7.1E-05 & $6.4 \mathrm{E}+03$ & $4.8 \mathrm{E}-05$ & $3.4 \mathrm{E}+03$ & $2.5 \mathrm{E}-05$ & ND & ND & $2.6 \mathrm{E}+03$ & $1.9 \mathrm{E}-05$ & $71 \%$ & $95 \%$ \\
\hline
\end{tabular}




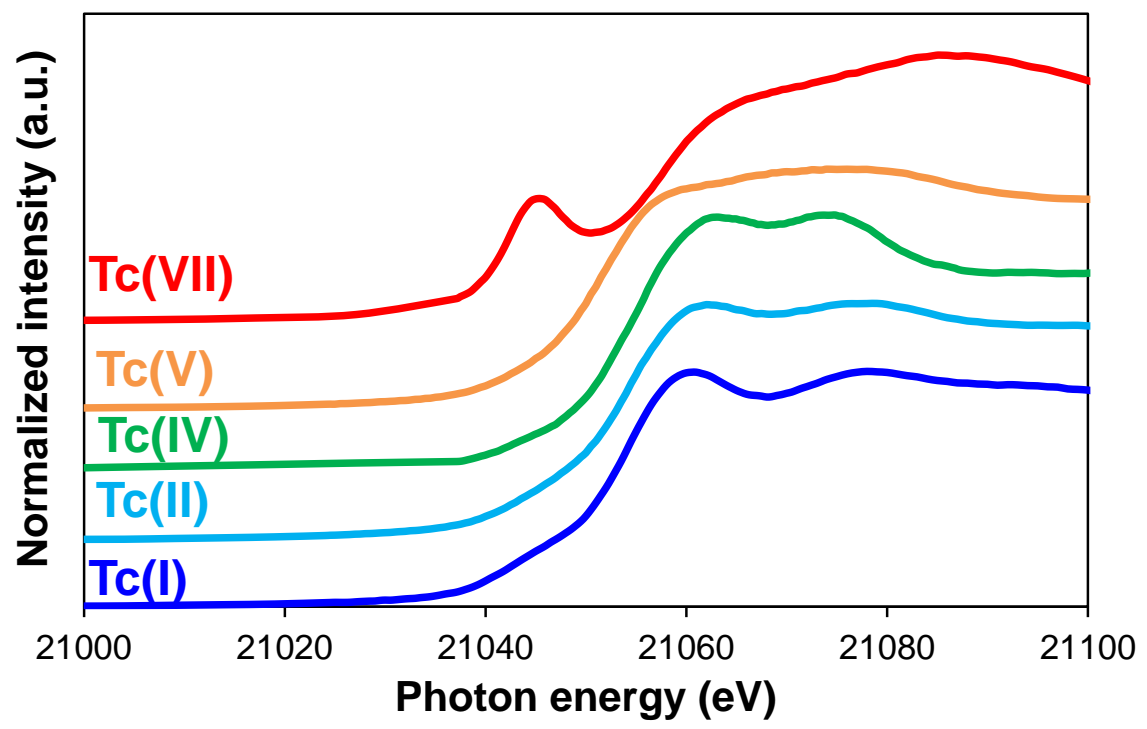

Figure S5. Tc K-edge XANES spectra for the various model Tc complexes (from top to bottom): red trace $-\mathrm{NH}_{4} \mathrm{TcO}_{4}$ in DI water, yellow trace $-\left(\mathrm{n}-\mathrm{C}_{4} \mathrm{H}_{9}\right)_{4} \mathrm{~N}\left[\mathrm{TcOCl}_{4}\right]$ solution in $\mathrm{CH}_{2} \mathrm{Cl}_{2},{ }^{13}$ green trace $-\mathrm{TcO}_{2} \bullet \mathrm{nH}_{2} \mathrm{O}$ generated electrochemically, ${ }^{13}$ light blue trace $-\left[\mathrm{Tc}(\mathrm{CO})_{2}(\mathrm{NO})\right]^{2+}$ in water, ${ }^{13}$ dark blue trace $-\left[\mathrm{fac}^{-}\right.$ $\left.\mathrm{Tc}(\mathrm{CO})_{3}(\mathrm{OH})\right]_{4}$ in water. ${ }^{8}$ 


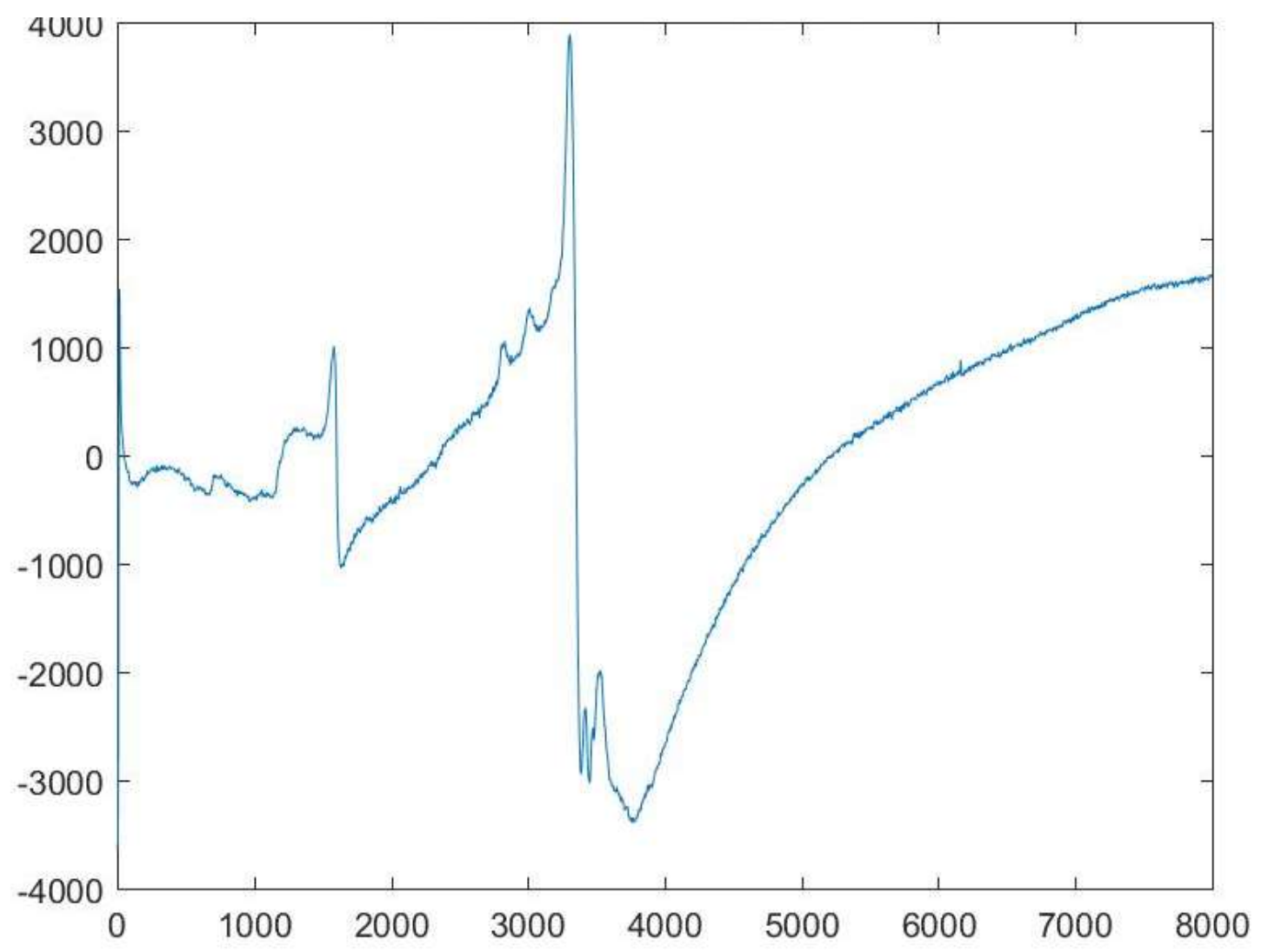

Figure S6. EPR spectrum collected on as-received AN-102 tank waste at $2.6 \mathrm{~K}$. 


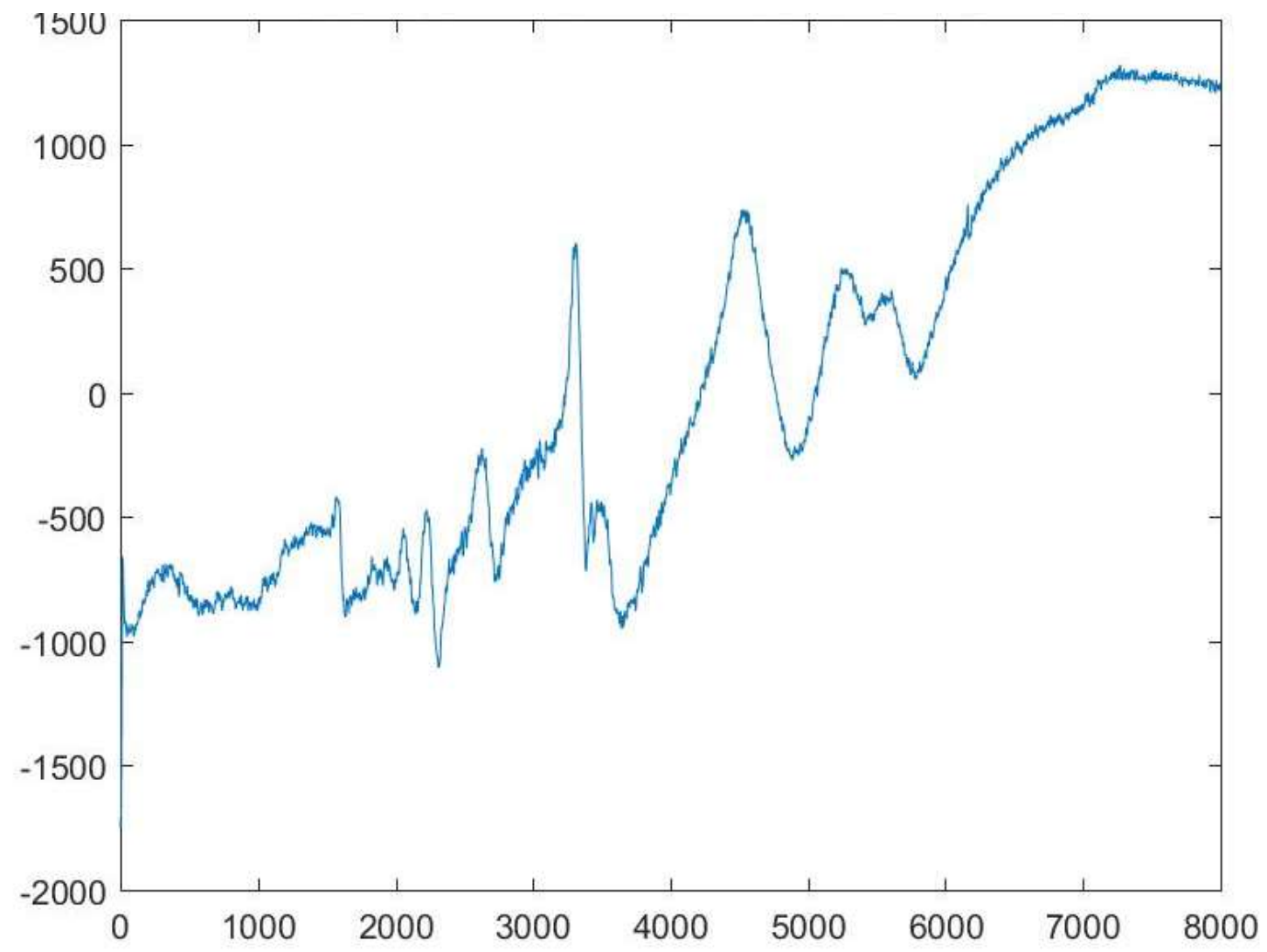

Figure S7. EPR spectrum collected on Cs-depleted AN-102 tank waste at $2.5 \mathrm{~K}$. 


\section{References.}

1. Cho, H. M.; de Jong, W. A.; McNamara, B. K.; Rapko, B. M.; Burgeson, I. E., Temperature and isotope substitution effects on the structure and NMR properties of the pertechnetate ion in water. Journal of the American Chemical Society 2004, 126 (37), 11583-11588.

2. Franklin, K. J.; Lock, C. J. L.; Sayer, B. G.; Schrobilgen, G. J., The Preparation of Technetium Oxyfluorides and Their Characterization by Tc-99, 0-17, and F-19 Nmr-Spectroscopy. J Fluorine Chem 1982, 21 (1), 36-36.

3. Webb, S. M., SIXpack: a graphical user interface for XAS analysis using IFEFFIT. Phys Scripta 2005, T115, 1011-1014.

4. Ravel, B.; Newville, M., ATHENA, ARTEMIS, HEPHAESTUS: data analysis for X-ray absorption spectroscopy using IFEFFIT. J Synchrotron Radiat 2005, 12, 537-541.

5. $\quad$ Chatterjee, S.; Del Negro, A. S.; Wang, Z. M.; Edwards, M. K.; Skomurski, F. N.; Hightower, S. E.;

Krause, J. A.; Twamley, B.; Sullivan, B. P.; Reber, C.; Heineman, W. R.; Seliskar, C. J.; Bryan, S. A., Electronic and Molecular Structures of trans-Dioxotechnetium(V) Polypyridyl Complexes in the Solid State. Inorg Chem 2011, 50 (12), 5815-5823.

6. $\quad$ Chatterjee, S.; Del Negro, A. S.; Edwards, M. K.; Twamley, B.; Krause, J. A.; Bryan, S. A., trans-K3[TcO2(CN)(4)]. Acta Crystallogr E 2010, 66, I61-U91.

7. $\quad$ Cotton, F. A.; Davison, A.; Day, V. W.; Gage, L. D.; Trop, H. S., Preparation and Structural Characterization of Salts of Oxotetrachlorotechnetium(V). Inorg Chem 1979, 18 (11), 3024-3029.

8. $\quad$ Chatterjee, S.; Hall, G. B.; Engelhard, M. H.; Du, Y. G.; Washton, N. M.; Lukens, W. W.; Lee, S.; Pearce, C. I.; Levitskaia, T. G., Spectroscopic Characterization of Aqua [fac-Tc(CO)(3)](+) Complexes at High lonic Strength. Inorg Chem 2018, 57 (12), 6903-6912.

9. Hall, G. B.; Andersen, A.; Washton, N. M.; Chatterjee, S.; Levitskaia, T. G., Theoretical Modeling of Tc-99 NMR Chemical Shifts. Inorg Chem 2016, 55 (17), 8341-8347.

10. Lukens, W. W.; Shuh, D. K.; Schroeder, N. C.; Ashley, K. R., Identification of the nonpertechnetate species in Hanford waste tanks, Tc(I)-carbonyl complexes. Environmental Science \& Technology 2004, 38 (1), 229-233.

11. Levitskaia, T. G.; Andersen, A.; Chatterjee, S.; Cho, H. M.; Peterson, J. M.; Rapko, B. M.; Walter, E. D.; Washton, N. Speciation and Oxidative Stability of Alkaline Soluble, Non-Pertechnetate Technetium. ; Pacific Northwest National Laboratory: Richland, WA, 2014.

12. Levitskaia, T. G.; Andersen, A.; Chatterjee, S.; Hall, G. B.; Walter, E. D.; Washton, N. M. Spectroscopic Properties of Tc(I) Tricarbonyl Species Relevant to the Hanford Tank Waste. ; Pacific Northwest National Laboratory: Richland, WA, 2015.

13. Chatterjee, S.; Andersen, A.; Du, Y.; Engelhard, M. H.; Hall, G. B.; Levitskaia, T. G.; Lukens, W. W.; Shutthanandan, V.; Walter, E. D.; Washton, N. M. Characterization of Non-pertechnetate Species Relevant to the Hanford Tank Waste.; Pacific Northwest National Laboratory: Richland, WA, 2017.

14. Rattat, D.; Schubiger, P. A.; Berke, H. G.; Schmalle, H.; Alberto, R., Dicarbonyl-nitrosyl-complexes of rhenium ( $\mathrm{Re}$ ) and technetium (Tc), a potentially new class of compounds for the direct radiolabeling of biomolecules. Cancer Biother Radio 2001, 16 (4), 339-343.

15. Rattat, D.; Verbruggen, A.; Schmalle, H.; Berke, H.; Alberto, R., [M(CO)(2)(NO)](2+), a new core in bioorganometallic chemistry: model complexes of $\operatorname{Re}(\mathrm{CO}) 2(\mathrm{NO})(2+)$ and $[\mathrm{Tc}-99 \mathrm{~m}(\mathrm{CO})(2)(\mathrm{NO})(2+)$. Tetrahedron Lett 2004, 45 (21), 4089-4092.

16. Urie, M. W.; Campbell, J. A.; Farmer, O. T.; Fiskum, S. K.; Greenwood, L. R.; Hoppe, E. W. Chemical Analysis and Physical Property Testing of 241-AN-102 Tank Waste-Supernatant and Centrifuged Solids. ; Pacific Northwest National Laboratory: Richland, WA, 2002. 